\title{
STUDI PROPAGASI VEGETATIF TANAMAN OBAT KAYU ULES (Helicteres isora Linn.) MELALUI STEK BATANG
}

\section{A Study of Vegetative Propagation on Medicinal plant of Kayu Ules (Helicteres isora Linn.) Through Stem Cuttings}

\author{
Dani Pamungkas', Siswadi' \& Gerhard E.S. Manurung²
}

\begin{abstract}
Kayu Ules ( or jamu. Plant propagation of this species is one problem need to be investigated as only few studies conducted on this. This research was undertaken to investigate the ability of Kayu Ules propagated through stem cuttings. The experiment was designed with completely randomized design (CRD) using 2 main treatments which werethe source of stem cutting materials including material from hard-wood, semi hard-wood and soft-wood stem. The second treatment was the use of commercial growth regulators, which were Atonik and Root-up. The result showed that cutting materials from soft-wood stem was not recommended due to very low survival. Meanwhile, the use of cutting material from semi hard-wood $(24 \%$ with atonik, $12 \%$ with root-up and $8 \%$ with control) and hard-wood stem (36\% with atonik, $24 \%$ with root-up and $20 \%$ with control)appeared potential to be used. This research recommended that there were six diameter classes of stem cutting showing ability to be propagated, which were diameter class I 5.86-7.6I mm (22.58\%), II 7.62-9.37 mm (45.I6\%), III 9.38-II.33 mm (22.58\%), IV II.I4-I2.89 mm (3.23\%), V I2.9-I $4.65 \mathrm{~mm}$ (3.23\%), and VI I4.66-I6.4I mm (3.23\%).
\end{abstract}

Keywords : Kayu ules, medicinal plant, vegetative propagation,stem cutting and diameter classes

\begin{abstract}
ABSTRAK
Kayu Ules (Helicteres isora) merupakan salah satu jenis tanaman obat yang dimanfaatkan buahnya untuk industri obat tradisional atau jamu. Perbanyakan tanaman merupakan salah satu masalah yang perlu dipelajari karena perbanyakan tanaman ini belum banyak dilakukan, selain itu perbanyakan dengan menggunakan biji sulit dilakukan karena rendahnya persen berkecambah. Penelitian ini dilakukan untuk mengetahui kemampuan tumbuh tanaman Kayu Ules melalui stek batang. Penelitian ini dirancang menggunakan rancangan acak lengkap (RAL) menggunakan dua faktor perlakuan utama yaitu perlakuan asal stek yang terdiri dari batang lunak, semi keras dan keras, serta faktor kedua adalah jenis zat pengatur tumbuh (ZPT) komersil yang terdiri dari Atonik dan Root-up. Hasil menunjukkan bahwa asal stek dari batang lunak tidak direkomendasikan untuk digunakan karena memiliki daya tumbuh yang sangat rendah. Sedangkan asal stek batang dari batang semi keras dan keras memiliki potensi untuk dipergunakan sebagai bahan stek batang Kayu Ules; dimana persen tumbuh pada batang semi keras adalah 24\% dengan atonik, $12 \%$ dengan root-up dan $8 \%$ dengan kontrol, sedangkan pada batang keras yaitu 36\% dengan atonik, 24\% dengan root-up dan 20 dengan kontrol. Penelitian ini merekomendasikan bahwa terdapat 6 kelas diameter batang stek yang menunjukkan kemampuan untuk dibudidayakan, yaitu diameter kelas I 5,86-7,6I mm (22,58\%), II 7,62-9,37 mm (45,I6\%), III 9,38-II $33 \mathrm{~mm}(22,58 \%)$, IV II, I4-I2,89 $\mathrm{mm}(3,23 \%), \mathrm{V}$ I2,9-I4,65 mm (3,23\%) dan VI I4,66-I6,4I mm (3,23\%).
\end{abstract}

Kata Kunci : Kayu ules, tanaman obat, propagasi vegetatif, stek batang dan kelas diameter

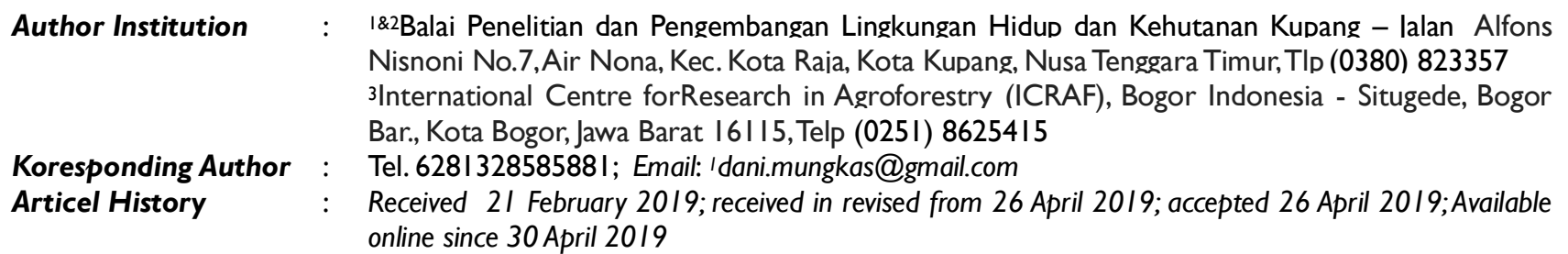




\section{PENDAhuluan}

Pemanfaatan tanaman obat telah menjadi alternatif selain obat pabrikan kimiawi sebagai solusi remedi. Beberapa jenis tanaman obat telah teridentifikasi dan telah memasuki skala industri dengan permintaan yang cukup tinggi. Pribadi (2015) mengungkapkan bahwa di Indonesia terdapat sekitar 31 jenis tanaman obat yang telah digunakan sebagai bahan baku pembuatan obat-obatan tradisional atau jamu. Proses perolehan tanaman obat ini yaitu 18 jenis dihasilkan melalui budidaya dan 13 jenis diperoleh melalui eksploitasi dari habitat alaminya dengan total permintaan lebih dari I.000 ton/tahun.

Kayu Ules (Helicteres isora) merupakan salah satu jenis tanaman obat yang habitat alaminya dapat dijumpai di Soe Nusa Tenggara Timur (NTT). Secara taksonomi, tanaman ini masuk ke dalam family Sterculiaceae (Pohocha \& Grampurohit, 200I). Tanaman ini juga banyak dijumpai di India dengan nama lokal di Tamil Nadu yaitu "Vallampurikai" (Sankaranarayanan et al., 20l0). Lebih lanjut, habitus tumbuhan ini berupa semak dengan tinggi dapat mencapai $3 \mathrm{~m}$ dan diameter batang antara 2,5 dan $5 \mathrm{~cm}$. Disamping itu, di habitat alaminya di NTT, tumbuhan ini memiliki jumlah batang yang bervariasi antara 7 hingga 12 batang dimana setiap batangnya tumbuh mengumpul pada pangkal batang tepat di atas permukaan tanah.

Penelitian tentang tanaman ini telah berkembang dan mayoritas fokus pada potensi obatnya. Buah Kayu ules memiliki kandungan biokimia yaitu zat antispasmodic yang umumnya digunakan untuk pengobatan rasa letih pada otot (Pohocha \& Grampurohit, 200I). Di Timor, secara tradisional buah dari kayu ules dimanfaatkan untuk pengobatan paska melahirkan (Siswadi et al., 2018). Selain itu, kulit batang Kayu Ules juga bersifat antioksidan dan memiliki kemampuan untuk memperbaiki kerusakan biokimia pada penderita diabetes, yang memiliki gangguan pada sel-sel beta yang memproduksi insulin yang disebabkan oleh agen kimiawi yang muncul secara alami yaitu streptozocin (diujikan pada tikus) (Kumar et al., 2006); sedangkan akarnya juga memiliki manfaat yang sama untuk penyembuhan diabetes (Venkatesh et al., 2004).

Akan tetapi, pengetahuan tentang teknik propagasi pada Kayu Ules masih sedikit diketahui. Ferdousi et al. (2014) menyebutkan bahwa tanaman Kayu Ules sangat sulit dilakukan budidayanya secara generatif atau melalui bijinya. Hal ini diperkuat oleh penelitian yang dilakukan oleh Muthukumar et al. (2017) yang menunjukkan bahwa pertumbuhan Kayu Ules menunjukkan pola penurunan viabilitas biji seiring periode pengamatan selama 24 bulan. Alasan argumentatif yang muncul pada laporan oleh Muthukumar et al. (2017) mengenai sulitnya perkecambahan biji Kayu Ules adalah bahwa di habitat alaminya Kayu Ules dapat memproduksi ribuan biji dan tersebar setiap tahunnya namun sangat sedikit biji yang dapat berkecambah.

Propagasi vegetatif menjadi alternatif untuk memperbanyak jenis ini setelah percobaan propagasi secara generatif pada Kayu Ules diketahui memiliki tingkat kesulitan yang tinggi. Penelitian oleh Ferdousi et al. (20I4) menunjukkan bahwa Kayu Ules dapat dikembangkan melalui stek batang. Rata-rata waktu yang dibutuhkan untuk inisiasi tunas baru dari awal penanaman dibutuhkan sekitar 32 hari, selanjutnya hingga pembentukan bunga dan buah masing-masing membutuhkan waktu selama 6 dan 7 bulan. Begitu pula 
dengan penelitian oleh Patel (2017) juga menunjukkan adanya keberhasilan dalam pembentukan tunas baru pada stek batang Kayu Ules. Disamping itu, mikropropagasi untuk perbanyakan Kayu Ules juga dapat dilakukan dengan menggunakan media MS dengan penambahan beberapa zat pengatur tumbuh (ZPT) seperti indole-3-butiric acid (IBA), indole-3-acetic acid (IAA) dan sitokinin (Meena \& Meena, 20I8; Shriram et al., 2007). Namun demikian, mikropropagasi ini membutuhkan biaya yang cukup tinggi untuk menghasilkan tanaman.

Namun demikian, penelitian - penelitian yang telah dilakukan tersebut memuat hanya sedikit informasi terkait perlakuan yang digunakan dan pola pertumbuhannya. Penelitian pertama oleh Ferdousi et al. (2014) hanya menunjukkan rata-rata waktu yang dibutuhkan bagi stek Kayu Ules dalam membentuk tunas baru dan menghasilkan formasi bunga. Sedangkan penelitian kedua oleh Patel (2017) tidak diketahui seberapa besar tingkat keberhasilan tanaman Kayu Ules melalui stek batang; serta kedua penelitian tersebut tidak menyebutkan teknik yang digunakan, seperti penggunaan ZPT.

Berdasarkan beberapa penelitian tersebut, maka penelitian ini dilakukan untuk mempelajari kemampuan tanaman Kayu Ules yang dibudidayakan melalui stek batang yang berasal dari beberapa sumber materi stek. Selain itu, penggunaan ZPT juga diujikan untuk mengetahui tingkat keberhasilan stek Kayu Ules.

\section{BAHAN DAN METODE}

\section{A. Lokasi dan Waktu Penelitian}

Penelitian ini dilakukan di persemaian yang berlokasi di stasiun penelitian Oilsonbai
Fatukoa, NTT. Penelitian dilaksanakan mulai November 2018 hingga Februari 2019. Saat melakukan penelitian, kondisi iklim mikro memiliki suhu minimal antara 22 dan $30,1^{\circ} \mathrm{C}$ serta suhu maksimal antara 29 dan $36^{\circ} \mathrm{C}$ dengan kelembaban relatif antara 69 dan $97 \%$.

\section{B. Alat dan Bahan}

Peralatan yang digunakan pada penelitian ini meliputi gunting stek, penggaris, ice box, thermohygrometer, kaliper digital dan polybag dengan ukuran 7,5 x 20 $\mathrm{cm}$. Bahan yang digunakan pada penelitian ini meliputi bahan stek Kayu Ules yang diperoleh dari habitat alaminya di Dusun Nesatanin, Desa Bosen, Kecamatan Mollo Utara, Kabupaten Timor Tengah Selatan (TTS) NTT. Lokasi berada di koordinat S 09²'34, I" dan E 124\%18'03,5" dengan elevasi $\pm 691 \mathrm{~m}$ di atas permukaan laut. Selain itu, digunakan pula dua jenis zat pengatur tumbuh (ZPT) komersil yaitu Rootup dan Atonik yang masing-masing memiliki bahan aktif yang berbeda seperti tersaji pada Tabel I.

\section{Metode Penelitian}

Penelitian dimulai dengan melakukan pengumpulan bahan stek yang diambil dari habitat alaminya. Bahan stek yang diambil adalah bagian batang kayu yang memiliki karakter kayu lunak (soft-wood), semi keras (semi hard-wood) dan keras (hard-wood), perbandingan dapat dilihat pada Gambar 2.

Perlakuan kayu lunak memiliki karakter kayu yang fleksibel dan merupakan kayu yang masih tumbuh, kayu semi keras memiliki karakter kayu yang agak keras dan masih fleksibel, sedangkan kayu keras memiliki karakter keras, kaku dan lebih berkayu. 


\section{Tabel I. Kandungan kimia ZPT yang digunakan pada penelitian} Table I. Chemical contents of two plant growth regulators

\begin{tabular}{ll}
\hline \multicolumn{1}{c}{ Atonik } & \multicolumn{1}{c}{ Root-up } \\
\hline I. Natrium para-nitrofenol $3.0 \mathrm{~g} / \mathrm{l}$ & I. I-Naftalenaasetamida $0.2 \%$ \\
2. Natrium orto-nitrofenol $2.0 \mathrm{~g} / \mathrm{l}$ & 2. Indole-3-butiric $0.01 \%$ \\
3. Natrium $5-$ nitroguaiakol $1.0 \mathrm{~g} / \mathrm{l}$ & 3. Thiram $4 \%$ \\
4. Natrium 2 -4 dinitrofenol $0.5 \mathrm{~g} / \mathrm{l}$ & \\
\hline
\end{tabular}

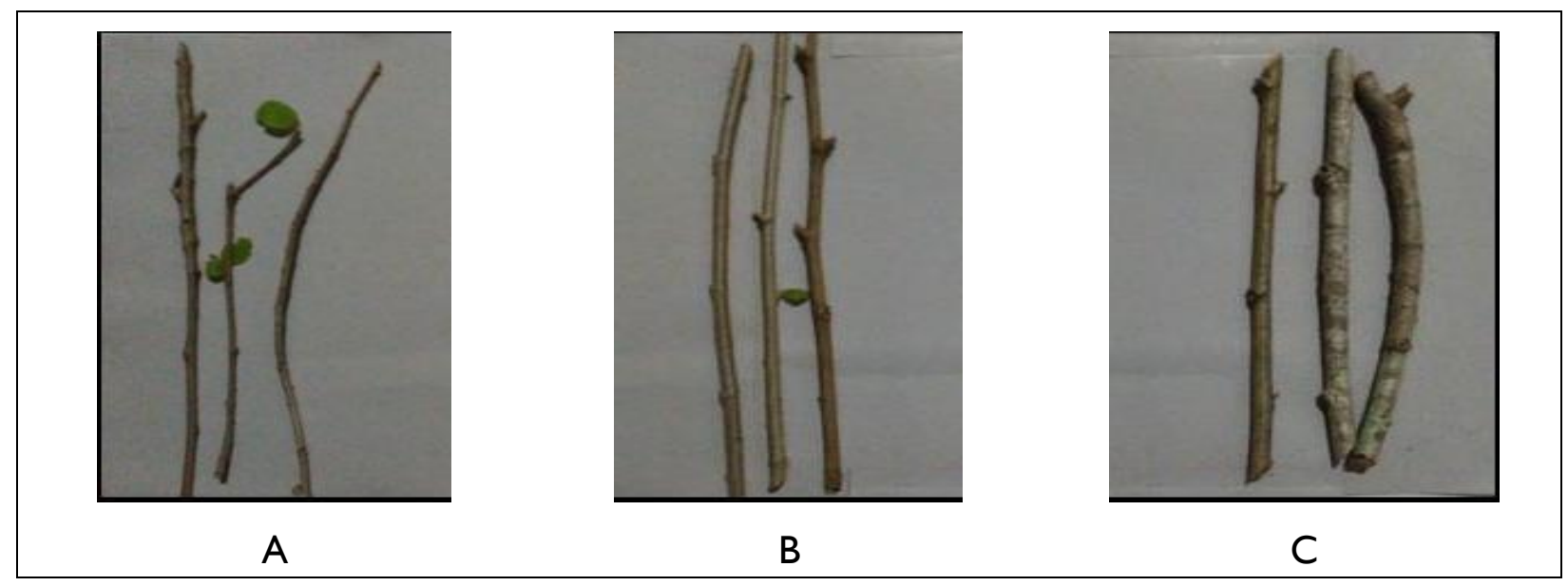

Gambar I.Variasi bentuk dan ukuran batang Kayu Ules pada tiga asal stek yang berbeda. A. Batang lunak, B. Batang semi keras, C. Batang keras

Figure I.A variation on shape and size of Kayu Ules cutting stem on three different sources A. Young stem, B. Semi-old stem, C. Old stem

Setelah bahan stek diperoleh kemudian dilakukan pengemasan secara baik untuk mengurangi resiko kehilangan air dan selanjutnya dibawa ke Stasiun Penelitian Oilsonbai. Jenis media tanam yang digunakan merupakan campuran dari tanah lapisan atas, pupuk kandang dan pasir dengan rasio 2:2:I (v/v) yang kemudian diisikan ke dalam kantong polybag dengan ukuran 7,5 cm x 20 $\mathrm{cm}$. Materi uji yang telah siap kemudian diletakkan dalam rumah sungkup untuk menjaga kelembaban tetap terjaga.

Penelitian ini didesain secara factorial yang menggunakan rancangan acak lengkap (RAL), dengan 2 faktor perlakuan yaitu faktor sumber stek dan penggunaan jenis ZPT. Sumber stek terdiri dari 3 taraf yaitu kayu lunak, semi keras dan keras. Ukuran stek batang yang digunakan memiliki panjang stek $25 \mathrm{~cm}$ (Ferdousi et al., 20l4). Faktor kedua adalah penggunaan ZPT berupa Atonik, Root-up dan kontrol. Setiap kombinasi perlakuan menggunakan 25 batang stek, sehingga diperoleh sebanyak 225 batang. Kombinasi perlakuan disajikan pada Tabel 2.

Penggunaan ZPT dilakukan setelah bahan stek telah dipersiapkan. Aplikasi ZPT Atonik yaitu dengan membuat larutan dengan konsentrasi l\% dimana $2 \mathrm{ml}$ cairan Atonik dilarutkan ke dalam $200 \mathrm{ml}$ air kemudian bahan stek direndam selama 30 menit. Sedangkan penggunaan Root-up dengan membuat larutan kental berupa $4 \mathrm{gr}$ bubuk ke dalam $20 \mathrm{ml}$ air, setelah itu pangkal batang stek diolesi larutan tersebut. 


\section{Tabel 2. Kombinasi perlakuan pada penelitian stek Kayu Ules} Table 2.Treatment combinations on stem cutting of Kayu Ules

\begin{tabular}{cl}
\hline No & \multicolumn{1}{c}{ Kombinasi perlakuan (Treatment combinations) } \\
\hline I. & Asal stek dari kayu lunak direndam dalam air selama 30 menit (kontrol) \\
2. & Asal stek dari kayu lunak direndam dalam larutan Atonik selama 30 menit \\
3. & Asal stek dari kayu lunak diolesi dengan Root-up \\
4. & Asal stek dari kayu semi keras direndam dalam air selama 30 menit (Kontrol) \\
5. & Asal stek dari kayu semi keras direndam dalam Atonik selama 30 menit \\
6. & Asal stek dari kayu semi keras diolesi dengan Root-up \\
7. & Asal stek dari kayu keras direndam dalam air selama 30 menit (Kontrol) \\
8. & Asal stek dari kayu keras direndam dalam Atonik selama 30 menit \\
9. & Asal stek dari kayu keras diolesi dengan Root-up \\
\hline
\end{tabular}

\section{Parameter dan Analisis Data}

Pengamatan terhadap pertumbuhan stek Kayu Ules dilakukan setiap 7 hari. Parameter yang diamati meliputi pertumbuhan jumlah tunas, jumlah daun, panjang tunas, persentase bertahan hidup, jumlah akar dan panjang akar. Parameterparameter ini dihimpun datanya untuk mengetahui sejauh mana tanaman stek Kayu Ules mampu tumbuh, berkembang dan bertahan. Selain itu, batang stek yang mampu bertahan hingga akhir pengamatan kemudian dilakukan klasifikasi kelas diameter. Penentuan kelas diameter dilakukan berdasarkan rumus yang dideskripsikan di dalam Hidayat \& Nurohman (2007) :

$$
\begin{aligned}
& R=D_{2}-D_{1} \\
& B K=I+(3,3 \log P) \\
& I=R / B K
\end{aligned}
$$

dimana,

$\mathrm{R}$ : range diameter populasi

$D_{1}$ : diameter terkecil yang diperoleh

$D_{2}$ : diameter terbesar yang diperoleh

BK: banyaknya kelas

$P$ : jumlah individu dalam populasi

I : interval kelas yang digunakan

Analisis two-way Anova dilakukan untuk mengetahui pengaruh perlakuan terhadap parameter pertumbuhan stek Kayu Ules. Uji lanjut Duncan's Multiple Range Test (DMRT) dilakukan untuk mengetahui tingkat signifikansi antar perlakuan pada $\alpha 0,05$. SPSS versi 23 digunakan untuk melakukan analisis.

\section{HASIL DAN PEMBAHASAN}

\section{A.Karakteristik Pertumbuhan Stek Batang Kayu Ules}

Perbanyakan tanaman Kayu Ules melalui stek batang menunjukkan kemampuan tumbuh tunas pada awal pertumbuhannya. Pada pertumbuhan lanjut, beberapa sampel asal stek batang dengan pemberian ZPT tertentu cenderung tidak mampu mempertahankan pertumbuhannya sehingga persen bertunas mengalami penurunan. Gambar 2 menunjukkan perbandingan pola pertumbuhan tunas stek batang pada beberapa penggunaan ZPT. Pertumbuhan dapat dilihat pada hari ke-I0 setelah tanam pada ketiga bahan stek. Awal pertumbuhan pada eksperimen kali ini dapat dikatakan 22 hari lebih cepat dibandingkan penelitian oleh Ferdousi et al. (20l4) dimana membutuhkan waktu selama 32 hari untuk pertumbuhan awal tunas. Respon pertumbuhan stek terhadap kematian dapat juga dikatakan dalam waktu yang singkat, terutama pada batang stek kayu lunak kematian stek dapat diketahui 
antara hari ke 45 dan 50.

Pada Gambar 2 diketahui bahwa penggunaan stek batang kayu keras memiliki keberhasilan tanaman tertinggi pada berbagai penggunaan ZPT (36\% dengan Atonik, 24\% dengan Root-up dan $16 \%$ dengan kontrol). Sedangkan, bahan stek dari kayu semi keras menghasilkan persentase hidup lebih baik (24\% dengan Atonik, 12\% dengan Root-up dan 8\% dengan kontrol) dibandingkan kayu lunak ( $0 \%$ dengan Atonik, 4\% dengan Root-up dan $0 \%$ dengan kontrol). Rendahnya keberhasilan pada stek kayu lunak diduga karena diameter batang yang kecil menyimpan cadangan makanan yang lebih sedikit sehingga kurang mampu menopang kebutuhan untuk pertumbuhan primordia tunas dan akar adventif. $\mathrm{Hal}$ ini memiliki kesesuaian dengan penelitian oleh Hidayat \& Nurohman (2007) yang menunjukkan bahwa peningkatan kelas diameter stek batang spesies Hopea odorata memberikan pertumbuhan yang lebih baik dibandingkan kelas diameter yang lebih kecil.

Stek batang yang memiliki diameter yang lebih besar umumnya memiliki cadangan makanan di dalam batang yang lebih besar dibandingan dengan stek batang yang lebih kecil (Panjaitan et al., 20l4). Simpanan karbohidrat dalam batang merupakan sumber energi yang digunakan untuk menumbuhkan organ-organ seperti daun yang berfungsi untuk melakukan fotosintesis. Energi yang dihasilkan dari fotosintesis yang kemudian digunakan juga untuk memacu pertumbuhan organ penting lainnya seperti akar adventif yang selanjutnya berfungsi untuk melakukan penyerapan nutrisi, sehingga siklus hara dapat masuk dalam tubuh tanaman.

Penggunaan ZPT diketahui juga memiliki pengaruh terhadap keberhasilan bahan stek. Seperti yang telah dijelaskan sebelumnya, penggunaan Atonik memiliki persen hidup yang lebih baik (36\% dengan kayu keras, $24 \%$ dengan kayu semi keras dan $0 \%$ dengan kayu lunak) dibandingkan dengan Root-up (24\% dengan kayu keras, I2\% dengan kayu semi keras, dan $4 \%$ dengan kayu lunak) dan kontrol ( $16 \%$ dengan kayu keras, $8 \%$ dengan kayu semi keras dan $0 \%$ dengan kayu lunak). Atonik yang mengandung senyawa natrium-nitrofenol diduga berperan terhadap percepatan pertumbuhan tunas selain penggunaan sumber energi dari batang stek untuk pertumbuhan tunas baru. Penelitian oleh Hidayanto et al. (20I4) menunjukkan bahwa penggunaan natrium-nitrofenol dengan konsentrasi tertentu memberikan hasil yang lebih baik pada bahan stek akar sukun (Artocarpus communis F). Penelitian ini juga menyatakan bahwa secara alami bahan stek telah mengandung natrium-nitrofenol endogen yang apabila diberi perlakuan tambahan yang tepat dapat mempercepat pertunasan.

Pada parameter pengamatan lainnya, stek batang kayu semi keras dan kayu keras dengan Atonik memiliki kecenderungan pertumbuhan jumlah tunas dan jumlah daun yang lebih baik dibandingkan dengan perlakuan lainnya (Tabel 3). Namun demikian, kondisi perakaran stek batang Kayu Ules cenderung lebih baik dengan penggunaan Root-up. Hal ini dapat disebabkan karena Root-up mengandung auksin sintetis berupa indole-3-butiric (IBA)(Tabel I). Senyawa ini juga banyak digunakan pada proses propagasi vegetatif untuk merangsang pertumbuhan akar sehingga memberikan pertumbuhan akar yang lebih baik dibandingkan penggunaan ZPT lainnya (Mahfudz et al., 2006). Oleh karena itu, pertumbuhan perakaran yang baik juga akan memberikan pertumbuhan tinggi dan diameter tunas yang baik pula. 


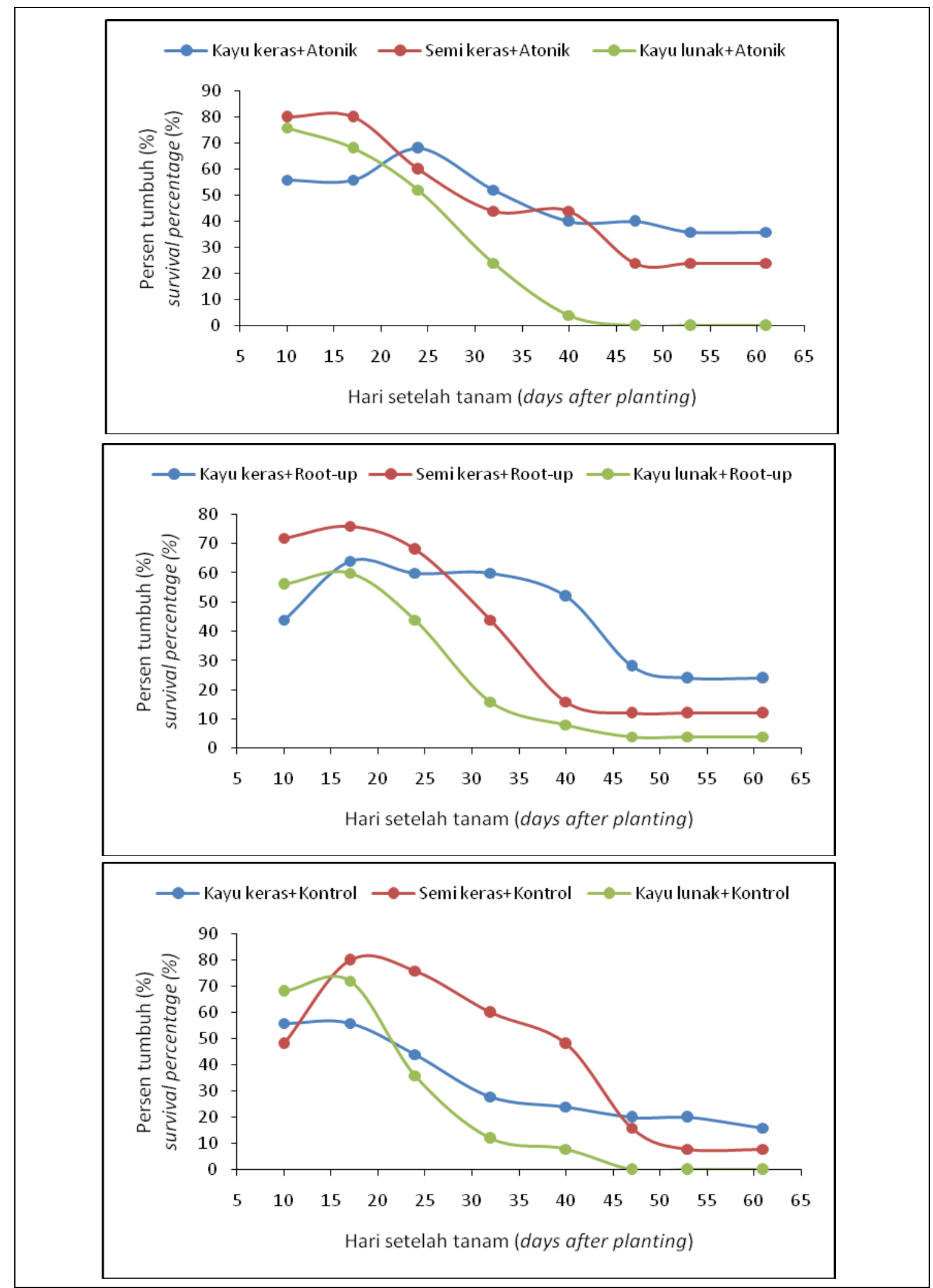

Gambar 2. Pola perbandingan persentase tumbuh stek batang Kayu Ules dari tiga asal stek batang dalam penggunaan ZPT yang sama

Figure 2. A Comparison pattern of cutting success of Kayu Ules from three sources in the same growth regulators 
Disamping itu, IBA yang juga secara alami terkandung di dalam tanaman dapat mempengaruhi perbesaran sel-sel organ tanaman seperti batang, akar, buah dan kalus. Maka ketika terdapat tambahan senyawa ini dapat memacu pertumbuhan tanaman (Atwell et al., 1999). Secara alami, IBA pada tanaman terkandung dengan jumlah yang lebih kecil dibandingkan dengan hormon lainnya seperti indole -3-acetic acid (IAA) yang juga memiliki peran untuk memacu perakaran (Epstein \& Ludwig-Müller, 1993). Konsentrasi hormon IBA ini meningkat seiring dengan tumbuhnya tanaman, namun tingkat konsentrasinya tidak pernah sama dengan konsentrasi IAA.
Hormon IBA juga diasumsikan memiliki tingkat kestabilan yang relatif lebih tinggi dibandingkan dengan IAA dalam memacu perakaran.

Pada perlakuan batang stek kayu keras+kontrol diketahui bahwa pertumbuhan batang stek secara rerata mampu melampaui perlakuan lainnya (terutama pada tinggi tunas $(18,43 \mathrm{~cm})$ dan panjang akar $(16,3 \mathrm{~cm}))$ (Tabel 3). Hal ini menunjukkan bahwa sesungguhnya tanaman Kayu Ules dapat dikembangkan secara vegetatif tanpa penggunaan ZPT, akan tetapi dengan konsekuensi memiliki persen yang lebih rendah dibandingkan dengan yang menggunakan ZPT.

\section{Tabel 2.Analisis sidik ragam pada beberapa parameter yang diamati} Table 2. Analysis of variance on several observed parameters

\begin{tabular}{lcccccc}
\hline $\begin{array}{c}\text { Sumber } \\
\text { Keragaman } \\
\text { (variance } \\
\text { sources) }\end{array}$ & $\begin{array}{c}\text { Jumlah tunas } \\
\text { (number of } \\
\text { shoots) }\end{array}$ & $\begin{array}{c}\text { Jumlah } \\
\text { daun } \\
\text { (number of } \\
\text { leaves) }\end{array}$ & $\begin{array}{c}\text { Tinggi } \\
\text { tunas } \\
\text { (shoot } \\
\text { height) }\end{array}$ & $\begin{array}{c}\text { Diameter } \\
\text { tunas } \\
\text { (shoot } \\
\text { diameter) }\end{array}$ & $\begin{array}{c}\text { Jumlah akar } \\
\text { (number of } \\
\text { roots) }\end{array}$ & $\begin{array}{c}\text { Panjang } \\
\text { akar (root } \\
\text { length) }\end{array}$ \\
\hline ZPT & 0,617 & 0,541 & 0,407 & 0,513 & 0,345 & 0,595 \\
Bahan stek & 0,226 & 0,421 & $0,003^{*}$ & 0,080 & 0,504 & 0,099 \\
Interaksi & 0,911 & 0,939 & $0,004^{*}$ & 0,173 & 0,119 & 0,061 \\
\hline
\end{tabular}

Keterangan: angka dengan tanda * adalah signifikan pada $\alpha 0,05$ menggunakan SPSS versi 23 Remarks: numbers with a sign * significant at $\alpha 0.05$ using SPSS version 23

Tabel 3. Rata-rata pertumbuhan stek batang Kayu Ules pada berbagai perlakuan Tabel 3.The average growth of Kayu Ules cutting stem on various type of treatments

\begin{tabular}{llcccccc}
\hline $\begin{array}{c}\text { Perlakuan } \\
\text { (treatment) }\end{array}$ & $\begin{array}{c}\text { Jumlah } \\
\text { tunas } \\
\text { (number of } \\
\text { shoots) }\end{array}$ & $\begin{array}{c}\text { Jumlah } \\
\text { daun } \\
\text { (number of } \\
\text { leaves) }\end{array}$ & $\begin{array}{c}\text { Tinggi } \\
\text { tunas (shoot } \\
\text { height) } \\
\text { (cm) }\end{array}$ & $\begin{array}{c}\text { Diameter } \\
\text { tunas } \\
\text { (diameter) } \\
\text { (mm) }\end{array}$ & $\begin{array}{c}\text { Jumlah } \\
\text { akar } \\
\text { (number } \\
\text { of roots) }\end{array}$ & $\begin{array}{c}\text { Panjang } \\
\text { akar (root } \\
\text { length) } \\
\text { (cm) }\end{array}$ \\
\hline Kayu & Atonik & $0.52 \mathrm{a}$ & $1.76 \mathrm{a}$ & $13,2 \mathrm{~b}$ & $1,6 \mathrm{I} \mathrm{ab}$ & $8 \mathrm{a}$ & $8,6 \mathrm{ab}$ \\
semi & Root-up & $0.28 \mathrm{a}$ & $1.04 \mathrm{a}$ & $14,1 \mathrm{bc}$ & $1.78 \mathrm{ab}$ & $1 \mathrm{a}$ & $9,6 \mathrm{ab}$ \\
keras & Kontrol & $0.32 \mathrm{a}$ & $0.84 \mathrm{a}$ & $6,17 \mathrm{a}$ & $1,3 \mathrm{a}$ & $5,5 \mathrm{a}$ & $5,9 \mathrm{a}$ \\
Kayu & Atonik & $0.68 \mathrm{a}$ & $2 \mathrm{a}$ & $14.13 \mathrm{bc}$ & $1,9 \mathrm{~b}$ & $4,67 \mathrm{a}$ & $9,33 \mathrm{ab}$ \\
keot-up & $0.52 \mathrm{a}$ & $1.44 \mathrm{a}$ & $14.73 \mathrm{bc}$ & $1.69 \mathrm{ab}$ & $7,33 \mathrm{a}$ & $8,57 \mathrm{ab}$ \\
& Kontrol & $0.56 \mathrm{a}$ & $1.56 \mathrm{a}$ & $18.43 \mathrm{c}$ & $1,86 \mathrm{~b}$ & $9,33 \mathrm{a}$ & $16,3 \mathrm{~b}$ \\
\hline
\end{tabular}

Keterangan: nilai rata-rata yang diikuti dengan angka yang sama adalah tidak berbeda nyata pada $\alpha 0,05$ berdasarkan uji lanjut DMRT

Remarks: the average value followed by the same number is not significantly different from $\alpha 0.05$ based on DMRT follow-up 
Kemampuan berakar batang stek dari berbagai asal tanpa menggunakan ZPT mungkin juga dapat diartikan bahwa dari sekian sampel yang digunakan, telah terjadi seleksi secara alami batang stek yang mana yang mampu tumbuh membentuk sistem pertumbuhan tunas dan akar. Dengan demikian, batang stek yang tumbuh dan bertahan merupakan batang yang memiliki kualitas terbaik dari segi fisiologis dan biokimia (kandungan hormon pertumbuhan endogen)(Ludwig-Müller, 2000).

\section{B. Karakteristik Pertumbuhan Tunas Dan Akar Stek Batang Kayu Ules}

Stek batang Kayu Ules yang memiliki pertumbuhan tunas yang baik cenderung memiliki perakaran yang baik pula. Secara visual hal ini dapat diketahui pada perakaran batang kayu semi keras yang cenderung memiliki perakaran yang lebih lebat (Gambar 3). Stek batang yang memiliki pertumbuhan tunas yang baik dengan daun yang lebih lebar dan lebih hijau memiliki sistem perakaran yang baik. Hal ini diduga bahwa pertumbuhan tunas memiliki hubungan terhadap pertumbuhan akarnya. Ini dapat dilihat pada grafik hubungan antara pertumbuhan tunas dengan jumlah akar $\left(R^{2}=0,1642\right)$ dan pertumbuhan tunas dengan panjang akar $\left(R^{2}\right.$ $=0,5342$ ) (Gambar 4) yang menunjukkan hubungan yang positif. Secara umum, tanaman yang memiliki tunas yang lebih tinggi akan membentuk perakaran yang lebih baik. Hal ini sejalan dengan penelitian yang dilakukan oleh Mahfudz et al. (2006) pada tanaman stek pucuk merbau bahwa sistem perakaran yang baik akan memacu pertumbuhan daun yang baik pula. Dengan bertambahnya daun maka bertambah pula tinggi tunas tanaman.

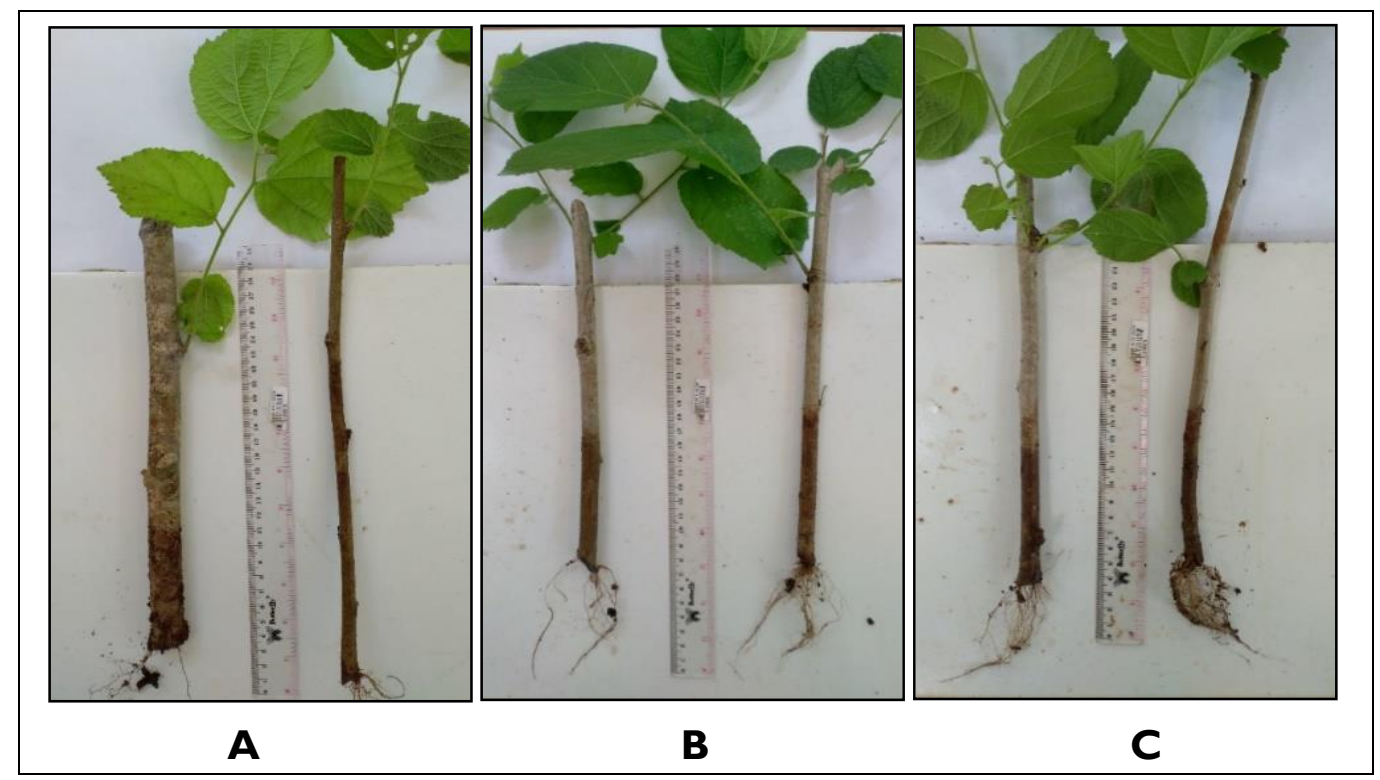

Gambar 3. Perbandingan pertumbuhan akar dan tunas pada perlakuan stek batang kayu keras (kiri) dan kayu semi keras (kanan), dengan menggunakan Atonik (A), Root-up (B) dan kontrol (C)

Figure 3. A comparison of root and shoot growth on the stem cutting of old stem (left) and semi-old stem (right,) with Atonik (A), Root-up (B) and control (C). 


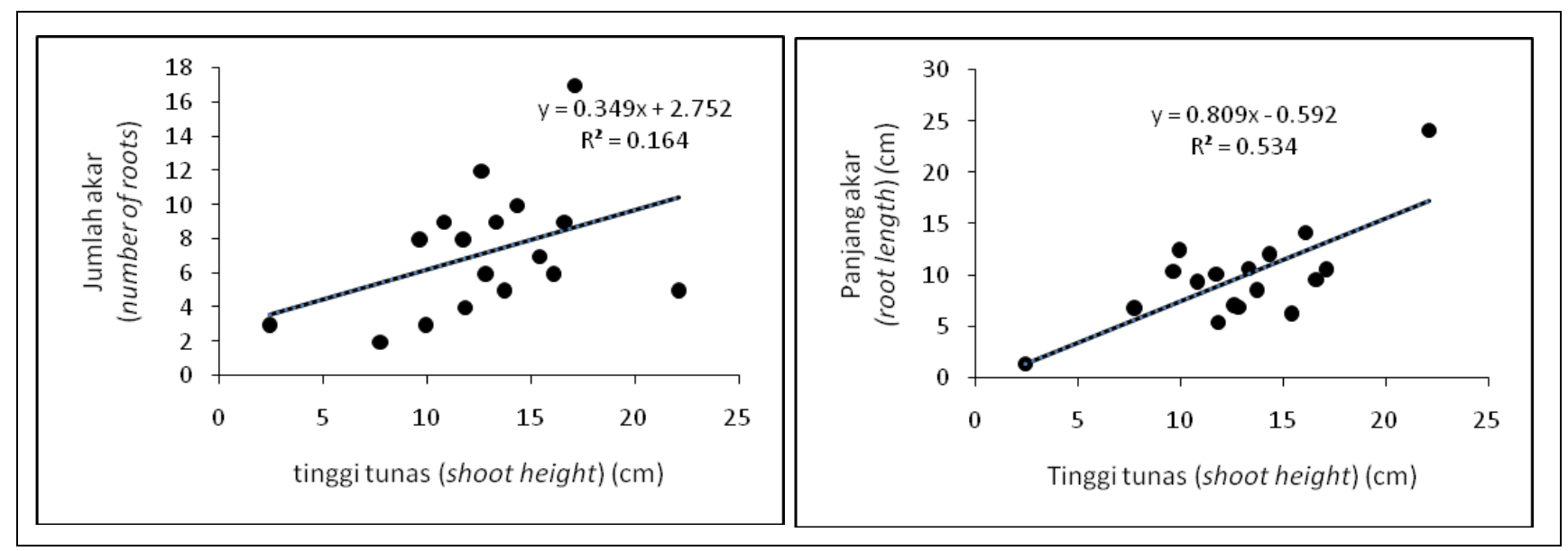

Gambar 4. Hubungan antara pertumbuhan tinggi tunas, panjang akar dan jumlah akar pada stek batang Kayu Ules

\section{Figure 4. a relationship between shoot height, root length and number of roots on stem cutting of Kayu Ules}

Dalam upaya budidaya tanaman secara makropropagasi melalui stek batang, kematian tanaman sangat mungkin dijumpai apakah tingkat kematian tersebut tinggi maupun rendah. Menurut Ludwig-Müller (2000), seseorang yang melakukan budidaya tanaman secara vegetatif akan menemukan kultivar kultivar yang dapat dikatakan sebagai mudah berakar (easy-to-root) dan sulit berakar (difficult-to-root), hal ini disebabkan karena adanya perbedaan metabolisme auxin di dalam tanaman. Tanaman - tanaman yang hanya mengandung sedikit konsentrasi IBA dalam tubuhnya cenderung sulit untuk berakar. Namun dengan penambahan IBA eksogen maka tanaman yang sulit berakar memiliki kemampuan untuk memacu pertumbuhan berakar.

Gambar 5 menunjukkan bahwa tanaman Kayu Ules mampu membentuk tunas primordia pada awal pertumbuhannya. Pada pertumbuhan tahap lanjut, tunas dapat tumbuh berkembang dengan memiliki beberapa tunas dan tumbuh dengan memiliki daun-daun yang cukup lebar untuk aktifitas fotosintesis. Namun demikian, beberapa tanaman dengan stek batang kayu lunak cenderung tidak mampu mempertahankan pertumbuhan yang kemudian layu dan akhirnya mengalami kematian.

\section{Klasifikasi Kelas Diameter Bahan Stek}

Pada akhir pengamatan, stek batang yang masih mampu bertahan dan memiliki akar kemudian dilakukan pencatatan diameter batang stek. Hal ini dilakukan untuk mengetahui kelas diameter yang memiliki potensi untuk dikembangkan lebih lanjut karena variasi kelas diameter pada tiap perlakuan sumber bahan stek cukup variatif. Selain itu juga sebagai langkah screening setelah diketahui mengenai penggunaan asal stek sebagai bahan pembuatan tanaman Kayu Ules secara vegetatif. Dalam hal ini, interval kelas diameter yang telah dihitung menurut rumus yang telah dideskripsikan di dalam Hidayat \& Nurohman (2007) menunjukkan interval sebesar I,75 mm. interval kelas ini yang kemudian digunakan untuk menentukan kelas diameter. 


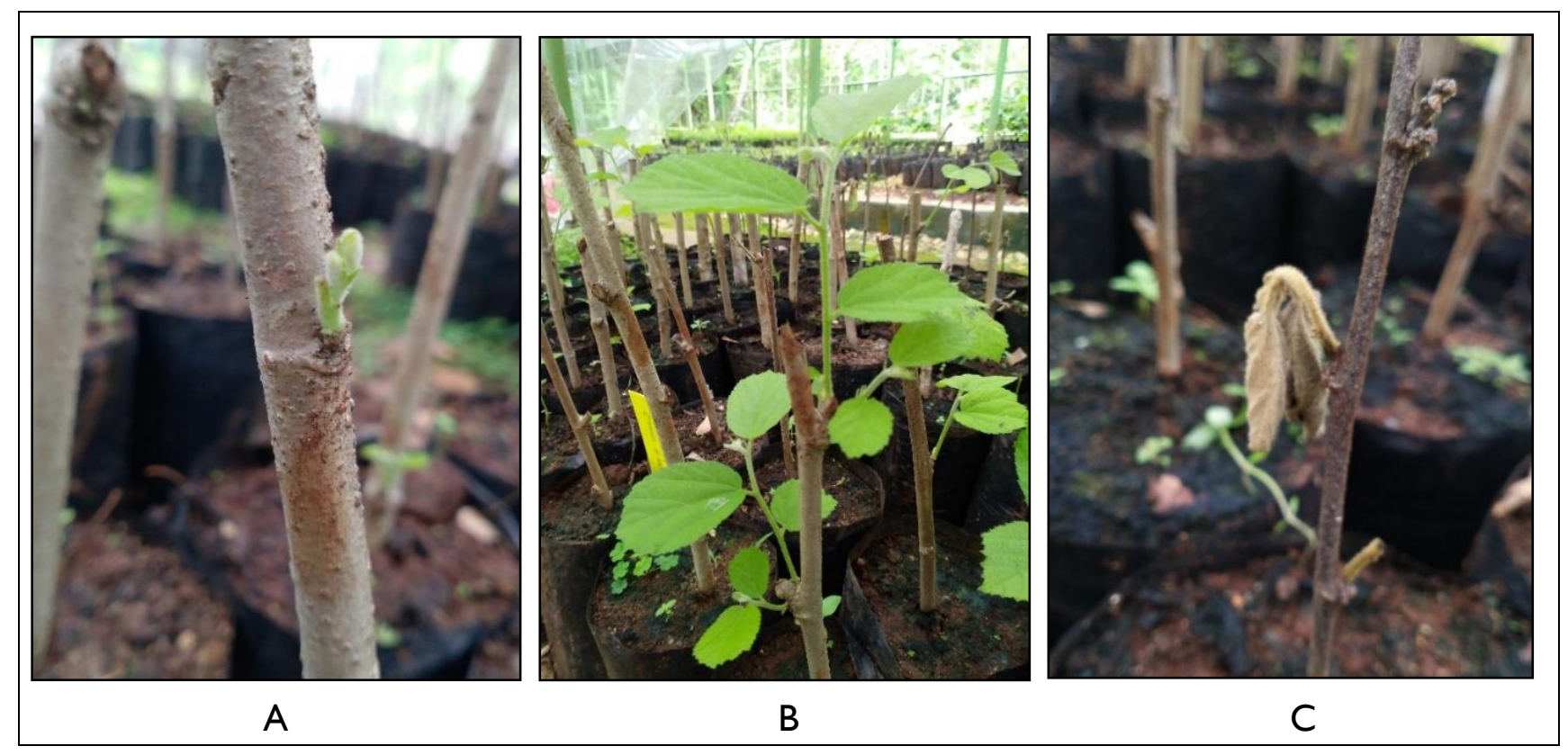

Gambar 5. (A) tunas primordia Kayu Ules, (B) tunas Kayu Ules yang telah berkembang lebih lanjut, (C) tunas primordia Kayu Ules yang mengalami kelayuan

Figure 5. (A) a primordial shoot of Kayu Ules, (B) an expanded shoot of Kayu Ules, (C) a dead primordial shoot on Kayu Ules

Tabel 4. Kelas diameter stek batang kayu ules dengan persentase bertahan hidup Table 4. Diameter classes of kayu ules cutting stem with survival percentage

\begin{tabular}{cccc}
\hline $\begin{array}{c}\text { Kelas diameter } \\
\text { (Diameter } \\
\text { classes) }\end{array}$ & $\begin{array}{c}\text { Interval diameter } \\
\text { (Diameter interval) } \mathbf{( m m )}\end{array}$ & $\begin{array}{c}\text { Rata-rata diameter } \\
\text { (Means of diameter) } \mathbf{( m m )}\end{array}$ & $\begin{array}{c}\text { Persentase } \\
\text { (Percentage) (\%) }\end{array}$ \\
\hline II & $5,86-7,61$ & 6,40 & 22,58 \\
III & $7,62-9,37$ & 8,63 & 45,16 \\
IV & $9,38-11,13$ & 10,15 & 22,58 \\
V & $11,14-12,89$ & 11,12 & 3,23 \\
VI & $12,90-14,65$ & 13,13 & 3,23 \\
\hline
\end{tabular}

Keterangan: hasil pengolahan data

Remarks: results of data processing

Tabel 4 menunjukkan bahwa terdapat enam kelas diameter dengan persentase tumbuh yang bervariasi. Kelas diameter II memiliki persentase tertinggi dimana diameter batang stek yang ada rata - rata sebesar $8,63 \mathrm{~mm}$. Selain itu, beberapa penelitian tentang teknik budidaya tanaman secara makropropagasi melalui stek batang dengan menggunakan diameter stek batang menunjukkan bahwa diameter stek batang memiliki pengaruh yang cukup nyata terhadap beberapa parameter seperti keberhasilan stek, perakaran dan pertumbuhan tunas (Hidayat \& Nurohman, 2007; Panjaitan et al., 20I4; Santoso et al., 2008). Stek batang yang berkarakteristik keras dan telah berkayu umumnya telah tua dan akan mengalami penurunan kemampuan dalam menghasilkan sistem pertumbuhan yang baru (akar dan tunas), dan stek batang yang terlalu muda 
terkadang juga tidak cocok digunakan sebagai bahan stek batang.

\section{KESIMPULAN DAN SARAN}

\section{A. Kesimpulan}

I. Asal stek batang berupa kayu semi keras dan kayu keras memiliki potensi untuk dikembangkan lebih lanjut sebagai bahan stek batang Kayu Ules.

2. Stek batang Kayu Ules yang berasal dari kayu semi keras cenderung memiliki pola perakaran yang lebih baik dibandingkan dari stek batang kayu keras.

3. Penggunaan ZPT berupa Atonik menghasilkan pertumbuhan tunas dan daun yang lebih baik dibandingkan dengan perlakuan lainnya, namun penggunaan ZPT Root-up memberikan sistem perakaran yang lebih baik dari pada perlakuan lainnya.

4. Terdapat 6 kelas diameter yang dapat digunakan sebagai acuan untuk membuat tanaman Kayu Ules dari stek batang, dimana kelas diameter II memiliki persentase keberhasilan tertinggi.

\section{B. Saran}

Hasil penelitian telah menunjukkan bahwa Kayu Ules memiliki potensi untuk dikembangkan melalui stek batang. Namun, penggunaan asal stek batang dari kayu lunak tidak direkomendasikan karena memiliki keberhasilan yang sangat rendah. Sedangkan asal stek batang kayu semi-keras dan kayu keras dapat dibagi ke dalam beberapa kelas diameter yang memiliki potensi untuk dijadikan bahan stek. Kelas diameter II (7,62 9,37 $\mathrm{mm}$ ) memiliki potensi terbaik sebagai bahan stek batang Kayu Ules. Oleh karena itu, penelitian lebih lanjut sebaiknya difokuskan pada kelas diameter yang telah diketahui, serta perlu dilakukan untuk mengetahui tingkat keberhasilan yang dapat dihasilkan.

\section{Ucapan terima kasih}

Penulis mengucapkan terima kasih kepada International Centre for Research in Agroforestry (ICRAF) yang telah mendanai kegiatan ini. Ucapan terima kasih juga disampaikan untuk Balai Penelitian dan Pengembangan Lingkungan Hidup dan Kehutanan Kupang, Kementerian Lingkungan Hidup dan Kehutanan karena telah memfasilitasi persemaian untuk melakukan penelitian. Secara personal kami ucapkan terima kasih untuk Obed Meto, Fedy, dan Min karena telah membantu kegiatan penelitian di persemaian Oilsonbai.

\section{DAFTAR PUSTAKA}

Atwell, B. J., Kriedemann, P. E., \& Turnbull, C. G. N. (1999). Plants in action : adaptation in nature, performance in cultivation. South Yarra: Macmillan Education Australia.

Epstein, E., \& Ludwig-Müller, J. (1993). Indole-3-butyric acid in plants: occurrence, synthesis, metabolism and transport. Physiologia Plantarum, 88(2), 382-389.

Ferdousi, A., Rahman, M. O., \& Hassan, M. A. (20/4). Seed germination behaviour of six medicinal plants from Bangladesh. Bangladesh Journal of Plant Taxonomy, 2 I (I), 7I-76.

Hidayanto, M., Timur, B. P. T. P. K., Hasyim, J. K. W., Sempaja, P., Nurjanah, S., \& Samarinda, M. F. P. U. M. (20/4). Pengaruh panjang stek akar dan konsentrasi natrium-nitrofenol terhadap pertumbuhan stek akar sukun (Artocarpus communis F.).

Hidayat, A., \& Nurohman, E. (2007). Pengaruh Ukuran Diameter Stek Batang Hopea odorata Roxb. Dari Kebun Pangkas Terhadap Kemampuan Bertunas, Berakar, Dan Daya Hidupnya. Jurnal Penelitian Hutan dan Konservasi Alam, 4(I), I- 12. 
Kumar, G., Murugesan, A., \& Rajasekara Pandian, M. (2006). Effect of Helicteres isora bark extract on blood glucose and hepatic enzymes in experimental diabetes. Die Pharmazie-An International Journal of Pharmaceutical Sciences, 6 I (4), 353-355.

Ludwig-Müller, J. (2000). Indole-3-butyric acid in plant growth and development. Plant Growth Regulation, 32(2-3), 219-230.

Mahfudz, M., Isnaini, I., \& Moko, H. (2006). Pengaruh zat pengatur tumbuh dan media tanam terhadap pertumbuhan stek pucuk merbau. Jurnal Penelitian Hutan Tanaman, 3(I), 25-34.

Meena, M. C., \& Meena, R. (2018). In Vitro Multiplication Of Helicteres isora Through Nodal Stem Segment Explant From Mature Plant. World Journal of Pharmacy And Pharmaceutical Sciences.

Muthukumar, M., Kumar, T. S., \& Rao, M. V. (2017). Phenology and seed germination of the Indian Screw Tree Helicteres isora L.(Malvales: Malvaceae). Journal of Threatened Taxa| www. threatenedtaxa. org, 9( I 2), I I040II 044.

Panjaitan, H., Richi, L., Ginting, J., \& Haryati, H. (20|4). Respons Pertumbuhan Berbagai Ukuran Diameter Batang Stek Bugenvil (Bougainvillea spectabilis Willd.) Terhadap Pemberian Zat Pengatur Tumbuh. Jurnal Agroekoteknologi Universitas Sumatera Utara, 2(4).

Patel, D. (2017). Stem cutting propagation of Helicteres isora Linn. in herbal garden. International Journal of Advanced Research and Development.

Pohocha, N., \& Grampurohit, N. D. (200I). Antispasmodic activity of the fruits of Helicteres isora Linn. Phytotherapy Research:
An International Journal Devoted to Pharmacological and Toxicological Evaluation of Natural Product Derivatives, I5(I), 49-52.

Pribadi, E. R. (20I5). Pasokan dan permintaan tanaman obat Indonesia serta arah penelitian dan pengembangannya. Perspektif, $8(1), 52-64$.

Sankaranarayanan, S., Bama, P., Ramachandran, J., Kalaichelvan, P., Deccaraman, M., Vijayalakshimi, M., ... Bama, S. S. (20I0). Ethnobotanical study of medicinal plants used by traditional users in Villupuram district of Tamil Nadu, India. J Med Plants Res, 4(I2), I089-I I0I.

Santoso, B. B., Susanto, S., \& Purwoko, B. S. (2008). Perbanyakan vegetatif tanaman jarak pagar (Jatropha curcas L.) dengan stek batang: pengaruh panjang dan diameter stek. Jurnal Agronomi Indonesia (Indonesian Journal of Agronomy), 36(3).

Shriram, V., Kumar, V., \& Shitole, M. (2007). In vitro propagation through nodal explants in Helicteres isora L., a medicinally important plant. Journal of Plant Biotechnology, 34(3), 189-195.

Siswadi, Umroni, A., Pamungkas, D., \& Manurung, G. E. S. (20I8). Pengaruh Pemupukan dan Penjarangan Terhadap Produktivitas Buah Kayu Ules (Helicteres isora) Di Desa Bosen, Timor Tengah Selatan, Nusa Tenggara Timur. Paper presented at the Optimalisasi Pengelolaan Hutan Berbasis Agroforestri untuk Mendukung Peningkatan Produktivitas Kayu dan HHBK, serta Pendapatan Petani, Bogor.

Venkatesh, S., Reddy, G. D., Reddy, Y., Sathyavathy, D., \& Reddy, B. M. (2004). Effect of Helicteres isora root extracts on glucose tolerance in glucose-induced hyperglycemic rats. Fitoterapia, 75(3-4), 364-367. 
Jurnal FALOAK Vol. 3 No.I April 2019: 29-42 